\title{
Ethics of Care and the Experience of Disability: an Interview with Eva Feder Kittay
}

\author{
Marivete Gesser ${ }^{1}$ (iD 0000-0002-4091-9754 \\ Helena Fietz ${ }^{2}$ (i) 0000-0002-6568-4760 \\ Universidade Federal de Santa Catarina, Departamento de Psicologia, Florianópolis, \\ SC, Brasil. 88040-900 - psicologia@contato.ufsc.br \\ 2Universidade Federal do Rio Grande do Sul, Porto Alegre, RS, Brasil. 90040-060
}

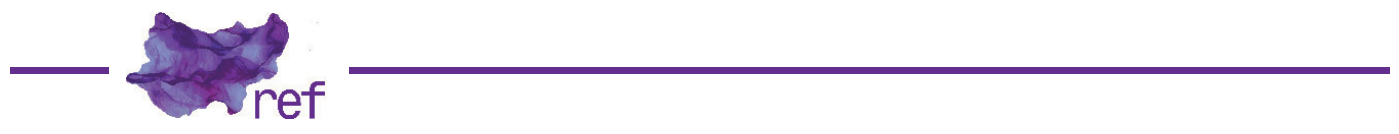

We met with Eva Feder Kittay in an afternoon of December at a café in New York City where she generously spoke for almost two hours about her work on the Ethics of Care and Disability, and her experience as Sesha's mother. A recently retired Professor of Philosophy from Stony Brook University, in New York, Kittay is a leading figure in feminist philosophy and philosophy of disability and has also made a substantial contribution to the fields of social and political theory and ethics. Along with other feminist theorists such as Joan Tronto and Virginia Held, Kittay was one of the pioneers in proposing an alternative ethical theory centered not on normative, general, universal principles of justice, but on interpersonal relationships, responsiveness to specific needs, and relationships of dependence and interdependence. An Ethics of Care. Her work as a philosopher is intertwined with her trajectory as Sesha's mother and she has built her career in a way that is not common within the discipline of philosophy: writing from one's own personal life.

She was also a pioneer in bringing matters of care and disability - with special attention to cognitive disability - into philosophy. In 1999 she published the groundbreaking book Love's Labor: Essays on Women, Equality and Dependency (Eva KITTAY, 1999). In this collection of essays, she presented a feminist critique of John Rawls' theory of justice and formulated an alternative conception of equality that takes into account relationships of care, dependency, and the dependency workers. With that, she argued for the recognition of Care as a primary good. Moreover, she placed dependency, interdependency, and care in the center of the discussions on social justice. She also argues for a better distribution of dependency work, one that is not by gender, race or class, but through skills or inclination which requires the valorization of such labor. Since then, she has published over eighty papers, books and book chapters on issues of dependency, the relational self, the relationship of care and justice, asymmetry of relationships, social justice, politics of care, and disability.

Kittay is also a prominent figure on Disability Studies. With a work grounded in an Ethics of Care, she has argued against philosophers and scholars who reduce the moral status of people with cognitive disability. With that, she addresses matters of the dignity of people with cognitive disability, personhood, justice, the role of care and of relationality, and also the guarantee of rights and access to health care for people with disabilities. She co-edited the book Cognitive Disability and its Challenge to Moral Philosophy (KITTAY; CARLSON, 2010) with Licia Carlson, and her new book Learning from My Daughter: The Value and Care of Disabled Minds (KITTAY, 2019) was published in April. 
Marivete Gesser (MG) and Helena Fietz (HF): We would like to start this interview asking you about how your history with Sesha influenced your work as a philosopher and, likewise, how your philosophical and theoretical approach may have influenced your life as Sesha's mother.

Eva Kittay (EK): I can start with the second question: how my philosophical and theoretical approach may have influenced my life as Sesha's mother. And, I can say: not very much. Because that's has been primary. My problem with philosophy is that it doesn't take into account people like Sesha. If I were to approach Sesha from a philosophical standpoint, a traditional philosophical standpoint, l'd have to approach her as a kind of non-person and that would be exactly the opposite of how any decent mother would relate to her child. I wouldn't say that my theoretical and philosophical life had influence on my approach to Sesha as a mother. But, rather, my life with Sesha has had a profound influence on my philosophical and theoretical work. When I first had Sesha and we first learned that she had very significant disabilities, my first instinct was to try to protect myself from the sort of devastating effects of that initial knowledge, and philosophy was a way to escape thinking about these sorts of things, these sorts of difficulties. In some of my work I quote Adrienne Rich who said that in her poetry and in writing her poetry she was nobody's mother and she needed that space where she was nobody's mother. For me philosophy occupied that space where I was nobody's mother for a long time. But even from the start it was clear that Sesha's life with intellectual disabilities was a challenge to me as someone who invested so much importance to a life of the mind, to thinking, to rational discourse. She already posited a challenge to me right from the beginning, but I didn't take up that challenge for quite a while. Several times I thought about wanting to write about this, but I didn't know how to do it yet. There was really no acceptable place in philosophy to write about these matters. There was no field of Philosophy of Disability when I started out. There was barely room for issues in feminism or race theory when I started out. But it was subjects like feminism and the ways in which being a woman impacted on both the subject matter of philosophy and the way one did philosophy that began to open the space for other considerations.

MG and HF: And how was it that you started to incorporate your experience as Sesha's mother in your work as a philosopher?

EK: I had gone to one conference early in the late 80 s that was about "mental retardation" - as it was then called. It was interesting, but I really felt that very few people there had very much understanding of the issue. They may have had sympathy for thinking about it, but there were things that I knew living so intimately with someone with this kind of disability that they simply didn't have access to. It was then that I determined that I would write about it at some point. What opened the floodgates was when Sarah Ruddick wrote a wonderful book called Maternal Thinking, (Sara RUDDICK, 1989) in which she showed how mothering, as an activity, involves thought through and through. But she was writing from the perspective of a white middle-class woman with children without disabilities. She was criticized for what some thought was a limited racial and class perspective - as well as its heterosexual assumptions. While she thought that while much of the criticism was unfair, she acknowledged that she couldn't speak authoritatively for experiences different than her own and she worked to be more inclusive, speaking extensively with mothers from different backgrounds. But there was one omission she readily acknowledged - she had not thought about disability. Following her publication of Maternal Thinking she edited a collection called Mother Troubles (Julia HANIGSBERG; RUDDICK, 1999), where she hoped to include a number of more difficult conditions for mothering. She asked me to write about mothering Sesha. That was that was the first time I put pen to paper in speaking of Sesha, and it just opened up so many issues, so many questions. At the same time, I was also invited to participate in a conference on prenatal diagnosis and selective abortion. Thinking about the issue from that vantage point was something I didn't relish. Nonetheless, these were the two instances where I first started to think about my life with Sesha and how Sesha poses a challenge to conceptions of the primacy of rationality, the role language plays in how we think about being human, the notions of what justice involves, and so forth. If you start thinking about these questions from the perspective of disability and especially cognitive disability (because you could work people with physical disabilities into the theories more easily than you could include people with mental disabilities), you have to question prominent theories. As I say in my new book Learning from My Daughter, I couldn't put the genie back in the bottle. It was just very compelling to write about and to think about the questions that emerged. It began more and more to overtake my concerns. At the same time the feminist issues I had been concerned with were relevant - this was the time when the ethics of care was developing. The feminist ethic of care fit very well with the kind of care that Sesha needed in her extreme dependency.

MG and HF: So, your first paper on this matter was "Not my way, Sesha. Your way. Slowly"?

EK: I don't know which came out first, "Not My Way, Sesha" or the Hastings Center paper about prenatal diagnosis and selective abortion, "The Expressivist Objection: Conversations with My 
Son." They were published very close together. But "Not My Way, Sesha" was certainly the first one I wrote. Because this was an interdisciplinary volume, I didn't feel constrained by having to write a philosophical article. I just wrote what I had been storing in my mind, but I didn't know how to begin to philosophize about my life with Sesha. Most of all, the paper just came pouring out of me almost in one fell swoop. I said to Sara Ruddick: "I don't know if this is a piece of philosophy. I didn't write it as such." And she said to me: "Eva, you feel philosophically." Sesha was 21 when I wrote that so that was 20 years of thinking and feeling that spilled out on the page.

MG and HF: In your book Love's Labor: Essays on Women, Equality and Dependency (KITTAY, 1999) and in your subsequent work, you talk greatly of dependency work and present care as a relationship of power without necessarily having to be one of oppression. We would like you to elaborate more on how inequalities of race, gender and social and economic contexts affect and are affected by relationships of care and dependency.

EK: Well these questions were among the first ways into the exploration of how Sesha's dependency mattered philosophically and, at the same time, connected her to my interest in ethical and political matters. I was fortunate enough to be able to hire people to help me with Sesha. I was perfectly aware that most people with children with disabilities were not so fortunate. Many women quit their jobs in order to be able to take care of their children. But it was very important for me to do my work--psychologically it was really important to me--and I was fortunate enough to be able to afford the help I needed to do this. That privileged position gave me a sense of what could be possible if the means were available for everyone who needed assistance. So, I felt an obligation to talk about what is possible if there is a political and social will to make resources available. My privilege also made me aware of the class and race disparities involved in care giving. While being able to employ a caregiver allowed me to do my work and be a mother both to Sesha and to my other child, Leo, it was also always uncomfortable. In addition, I was most fortunate to have hired someone, Peggy, who stayed with Sesha for so long (over 25 years), but never bought into the idea that in taking care of your child she becomes "part of the family." Peggy resisted that coupling, and I appreciated it very much. She was always her own person. She had her own family. Sesha was very important to her, but she was doing this as a job - which she did superbly-- not as a member of the family.

The ethics of care always has to be a politics as well as an ethics. The relationships of power between caregiver, care receiver, the person who is responsible for hiring the caregiver, are all enmeshed in power dynamics. It's obvious that the caregiver has power over the cared for. The caregiver has that power by virtue of the incapacities, particular vulnerabilities, and the dependencies of the person who needs care, assuming now that the person being cared for needs care and is not getting care merely because they are in a privileged position to demand care of another. That power is there to serve the cared for. For that reason, it has seemed to me that power inequalities as such are not inherently and not always pernicious. The political issues that need to be addressed come when power is used to oppress and dominate. We most easily see this domination in the way the caregiver is treated - although it is surely also the case that caregivers can abuse their power over the cared for. Still, it is often the caregiver who is subject to oppressive abuses of power inequalities. Given the economics of caregiving--as it is carried out in the here and now - we wind up with relationships of domination visited upon the caregiver by those who do not do the caregiving but want to see it done. This is not an inevitability. It's just the way it's been done. After all, most caregiving has been done for free. Not for free really, but on the backs of women, right? That's been the tradition, and so when it is paid, it gets the lowest pay because you could, in theory, get it for free. It's not that caregiving can be had for free just in theory. It's actually in practice that you can get it for free. So why should you have to pay somebody? And if you pay someone you pay them a pittance.

It's always been people with low economic means and status who are called on to do carework. In the US it's mostly poor women and women of color, as it also is in Brazil. African American women once did the bulk of paid domestic work in the US. Today African American women are less likely to do this work -- the work to which they had been relegated -- now that they have been able to avail themselves of other opportunities. But it's still the work many women of color are consigned to do: Latin American women, Asian women and women of African Caribbean descent. Color, race and class define who does the work of paid caregiving.

How does one begin to deal with the inequities? Well, in Love's Labor I argued that all caregiving needs to be paid. No free caregiving. Of course, that's a utopian idea at this point. But not so entirely utopian. Some European countries, especially the Nordic ones have something like mother's - a parental caregiver's - pensions or they may receive paid leave from other employment. These monetary incentives can be given for the wrong reasons. Sometimes the motive is to give mothers an incentive to have children for nativist reasons - increase the number of persons who are ethnically similar - or the intent is to keep women at home and so ossifying 
traditional female roles. But such pensions and compensations can be an acknowledgement that caregiving is labor - and like any other labor ought to be paid.

Several things are necessary if we want to see change. Consider what is needed to treat this work as something that can confer status and can garner an income commensurate with how difficult it is to do this work and do it well. It first requires that we recognize caregiving is work. It needs to de-gendered and de-naturalized. Instead we need to treat caregiving as a skill to be cultivated, which gives rise to a career that has a ladder one can climb, that is, caregiving must not be a "dead-end job". As long as we fail to give caregiving its due, caregivers and those who are cared for both lose.

Because of so-called scarce resources - which aren't always scarce- those who give care and those who receive it are set against one another. People who need to hire caregivers (either for themselves of for a parent or a child) want to fight getting caregivers a minimum wage and benefits other workers receive. That needs to change. We need solidarity; we need to form coalitions between caregivers and people who need care. Furthermore, we need to push back against the plea that we cannot afford to increase the cost of caregiving, push back against the excuse of scarcity. Because, really, in a country like the U.S., resistance to paying caregivers more is not about scarcity. There's plenty of money in this society to pay well for care. It's a question of political will, not a question of scarcity. In some places, there is a question of scarcity, but in those countries pay is generally less, and labor is less scarce. There are different issues, but they're not necessarily ones that have to maintain the exploitative way in which we now structure caregiving (or dependency work, as I call the kind of caregiving in question). One thing l've been arguing for lately is that we need to have the disability community (which has developed a political voice) and caregivers come together - form a coalition - rather than see the need for more assistance to disabled people and the need for higher wages for caregivers as a zero-sum game.

MG and HF: Could you tell us a bit about how your work and other feminist care theorists have impacted the production of knowledge in the US?

EK: A lot of books. More recognition in the academy. Care Ethics is sometimes now taught along with some of the traditional ethical theories. It's still not mainstream. But, as I like to point out, virtue ethics has been around since Aristotle. Deontological ethics has been around longer than Kant. Utilitarianism since Hume. We have only had 30 years or so. If we had 30 years and we are not yet in the mainstream, it is not so surprising. It's a long process before an ethical ideal or an ethical theory takes hold. I don't really know its impact in other disciplines. It's hard for me to judge. It seems to me that sociology has taken care theory on-board and anthropology has to some extent. Certainly, nursing schools teach care ethics. But care theory is not yet a fully developed theory. Still it has had some impact on knowledges. Has it had an impact on policy? Not so much. Though there are more advocacy groups pushing for better benefits for caregivers, more childcare and eldercare and the disability movement is actively seeking more access to care or personal assistance. It's in the area of policy that you want a faster impact. We can't wait 200 years.

MG and HF: Feminist scholars such as yourself, Joan Tronto, Virginia Held, and Carol Gilligan have been long talking about an Ethics of Care. What is an ethics of care for you and what is its importance for your work?

EK: Well, ethics of care is central to my work. I see the ethics of care as being important to disability studies - it's a case I try to make because a lot of disability theory is hostile - I don't think that's too strong to say hostile - to the notion of care. At least there are certain strands that are hostile to care. An ethics of care, as I just said is still early in its development, even if it is no longer in its infancy. And there's not one ethics of care right now. There are several different versions. I think all of us, Joan Tronto, Virginia Held, Carol Gilligan, Nel Nodding and many more have never regarded an ethics of care as being only an ethics of interpersonal relationships. The articulation of an ethics of care may start there, but I don't think any of us thinks that it ends there. So, I think in developing an ethics of care what all of us have tried to do in various ways is to show how and where an ethics of care is important outside of interpersonal relations. I'm not sure what Gilligan's view is on this now, but certainly for Held, Tronto, myself, and others--most of us no longer accept a juxtaposition, an opposition between care and justice. We have all pondered the relationship is between care and justice. My current way of thinking about it - and I'm not sure this is right, it's something I'm playing with and trying out - is that while an ethics is about the interpersonal, justice (taking this now from Rawls's formulation) is primarily a virtue of institutions. If that's the case, then care and justice are not opposed to one another, but they operate on different planes. I take it that most theories of justice have some kind of underlying understanding of what an ethics is. So that, for example, Aristotle's conception of justice is based on a virtue ethics. The point of the Polis is to allow for the cultivation of the person who can achieve happiness, or what Aristotle called the activity of the soul in accordance with virtue. Jumping ahead to the present, a theory of justice 
such as Rawls is based on the Kantian Ethics. The point of the state is to allow people to develop self-respect, which from a Kantian point of view is the most essential thing: to be able to act as a self-respecting person, acting out of goodwill. In a Kantian ethics, right action, which leads to self-respect, takes priority over happiness. What does a theory of justice look like if you take an ethics of care as the central ethical perspective? Rights that we can claim for ourselves or that others insist upon would not have quite the importance that they have in the theory of justice. Instead, the importance of acting in accordance with our own or another's rights needs to be reconciled with the need to honor our responsibilities - especially responsibilities that we have toward dependents. Such a theory of justice would need to take dependence rather than (or along with) independence as central to our thinking about the sorts of social institutions we want to have. And so forth. I'm thinking about how would you conceive of a theory of justice if you take an ethics of care as the ethical perspective in a just society?

Another place where I think l'd like to see work done is on how you take an ethics of care into institutions. We have certain institutions that have as their aim taking care of people, social welfare systems, for example. But those very systems can be quite uncaring. It's not so easy to see how an ethics of care that deals with the particularity of the individual - the concrete other-- can be the central virtue of institutions that deal with the generalized other. Nor is it easy to see how the particular needs we have as individuals are truly satisfied once they become incorporated into a generalized set of needs that are then dealt with according to rules that overlook the different situations of distinct individuals. Yet how well you meet the particular needs of particular persons will be the difference between successful caring and the failure to care. Furthermore, institutions that are meant to address needs often do not consider if they are addressing these needs in the right manner. For example, it isn't sufficient to give people something to eat if you pay no heed to whether what you are feeding someone is something that person finds inedible; similarly, satisfying another's hunger isn't yet caring if the food is served in a manner to humiliate the other. Those things are important in an ethics of care and depend on the particular situation, needs, and wants of individuals. Squaring the emphasis in ethics of care on particularity and the rule-governed generalizations of institutional structures is a real challenge. One that has both theoretical and practical importance. These are all questions that I think need development if we are to have a robust ethics of care, one that doesn't just describe what some practices are, but tells us both how care should be and how broadly an ethics of care may apply.

MG and HF: Can we say that nowadays care is perceived more as a public matter than it was when you started your work?

EK: I wish. But l've been thinking that as we have more people aging, because the world is aging, and fewer people who can take care of the aging (especially the aging of people they love), care will become more of a public matter. This is especially true if women continue to participate in the public sphere and continue to be expected to help to bring in income. If women continue to try to become equals in the workplace at the same time as the need for care increases, we're going to have to see care become a more public matter. That's my hope. My hope is that--in spite of all the ways in which we're backtracking--these changes in our demographics will force positive change. That means we have to be prepared with theories and with ideas how to do these things well, that is, in a just and caring manner. In a way, that's how I think about my work right now. That we're doing this underground work. Waiting for the moment when it'll be the right time for these ideas to be taken up.

MG and HF: While working with the concept of care, it is common to hear criticism about how broad the concept can be. Have you encountered such criticism and how do you respond to it? EK: This is why I say that an Ethics of Care needs a lot more work. And we need to decide if we're going to limit ourselves to theorizing care as it's currently done, and which has been based on an unjust sexual division of labor. Because the sexual division of labor as we've seen it is an unjust system. Care is often done badly, and not everything that we call care is really care. It's done well enough so that we've survived, and even thrived as a species, but it's certainly something that needs to be done better. As successful as we have been from an evolutionary perspective, - we have a long way to go to be successful from a moral perspective. We need a stronger normative sense of care. That is to say, we need more thought about what care should look like and what kind of so-called care is really uncaring? Sure, care as a value and a concept can be very broad. But even so, we need to know what it is that we're talking about when we think of care normatively. It's got to be something more than just a sentiment. One important thing that feminist conceptions of care have insisted upon is that care is labor as well as an attitude or emotional state. It has to be something that is laudatory; it's got to be something good. But intending the good in the case of care is insufficient as care: it must involve labor and it needs to meet its mark. It needs to successfully meet important needs and wants of people, especially when the people involved cannot meet these alone. 
MG and HF: In your work, you question contemporary philosophical concepts of personhood and what it is to be a human. We can recall a very contentious exchange you had with philosopher Peter Singer on morality and personhood. Based on your previous views and current work, would you mind telling us a little bit more about personhood?

EK: Well, I have taken the relational turn. I think personhood is relational. You asked me before about some "mother's child". When I was thinking about equality in "Love's Labor" I was asking what do all human beings have in common? And what we have in common is that we are all some mother's child. By this, I mean not only have we been born of a woman's body, but we also have to have been nurtured by another--whatever gender that nurturing person or persons may be. I don't think there's any inherent trait that we have that makes us equal. I think there's no inherent trait that makes us a person; there is not a set of necessary and sufficient conditions that we need to satisfy for personhood, that is, if we think of those conditions as intrinsic properties. We are persons because we participate in the human community. Well, I should go back. In philosophy, the notion of personhood is distinguished from the mere fact of our humanness. Philosophers may be the only people who think that being human isn't sufficient for being morally significant/ or morally equal. But I do believe that being human is sufficient for being a moral equal. And in fact, when you are mistreated in certain important ways, what do you say? You say "how can you treat me this way. I'm a human being". Not I'm a person. You can say that but most of the time what we say is "I'm a human being". People like Peter Singer don't think that being a human being is morally significant. The notion of personhood goes all the way back to Locke. Locke said there's man and there's moral man. Only the latter is equivalent to personhood - as having the same moral importance as all other persons. The notion of personhood can be useful if you want to include non-humans into the category of those who have full moral status. It may be possible to include certain animals - at least for certain purposes. Maybe someday aliens will land on this planet, and we will want to say that they are persons too. But I want to say however you define personhood it has to be a way that includes all human beings regardless of their rational (or any other particular) capacity. I want to say, first of all, that a sufficient, if not a necessary, condition to be a person is to be born to human parents. For me that is enough - it is all I need, for example, to make the argument that someone ought to get the same level of medical treatment as anyone else, for example. This is the sort of being who you don't eat. This is the sort of being that you oughtn't use only for your own means. These are examples of the sort of very stringent moral demands that apply to anyone who is born to human parents. Born to human parents--that's it, that's all. Now, you could say there are other things we shouldn't eat, or other things we shouldn't treat merely as means to our own ends. I have no quarrel, in principle, with making these claims. But the way we see other beings as having moral significance derives from similarities with those aspects of being human that we believe we need to respond to morally. That is an argument I make in one of my most recent papers: "The Moral Significance of Being Human" (KITTAY, 2017). If we encounter a being in whom we can recognize nothing that resembles what believe we ought to respond morally in humans, then we have no idea what it means to treat them morally. In this sense, human beings are the measure of all things moral (to borrow from Protagoras, the ancient philosopher who said that "man is the measure of all things"). Some people counter that this is too anthropocentric. And I would say we have no other choice.

People like Peter Singer want to say moral status has to do with certain sorts of capacities. Rationality and a few other psychological capacities count for the full moral status we accord to humans, and it is by virtue of these that we should attribute comparable status to nonhumans. It's the rationality that counts for moral status, not the humanness. I think this is no less anthropocentric than the view I have expressed. But, as I see it, an appreciation of rationality and other so-called higher psychological states are not what we as humans value first. Those aren't things that are the most foundational for our moral understanding of another individual. When we have a baby, an infant, we don't know any of the specific characteristics that infant is going to have. But we have a commitment to take care of them. Not because they will have this capacity or that capacity, because we can't know these things for sure. We don't know the features and capacities this particular individual will develop. But we have a commitment to care for the infant just because it was born human. That child was born to us, whether it was born into our family or we found him in a basket in the bulrushes (as the Pharaoh's daughter found baby Moses) - and that is enough to command of us that we care for the child. Each human being is born into the family of humans. As such, we have a similar basic commitment to every single human being - one we are justified in violating only if that other human being poses a grave threat to us. As the child grows, we can point to talents and capacities that ought to be cultivated, to emotional and physical needs that we need to satisfy, and to a variety of ways we ought to respond to and treat that individual. All that is parasitic upon the fundamental commitment we need to have to them as moral equals - as persons. That's what I want to say about personhood. So that it has nothing to do with rationality. It has nothing to do with anything else. Except being born human. 
MG and HF: Continuing on this topic, what does it mean to shift the centrality of what constitutes a human from rationality to relationality?

EK: Well that's basically it. It's the relationality of humans to humans. That is what it means to be some mother's child. Which is not to say that we can't be in relation to non-humans. We do have all sorts of moral obligations to non-humans. Certainly, to any non-human whom we have made dependent on us. I have an obligation not to throw my dog out of the house to let him fend for himself. I have an obligation to feed my dog because I have established a relationship to him. Because I have brought him into my home, he has come to dependent on me, and that obliges me to meet the demands of that dependent relationship. So that's true of a being whether or not it is human. But it's always true of humans--except if they're trying to destroy you. That's how we understand a very stringent moral obligation, the obligation to the strangers, which, of course in our own country, now we're absolutely violating. Leaving the stranger at the door or kicking them out - unless they pose a genuine threat - is unconscionable. It's a violation of a relationality we should recognize, and which applies to all humans. The idea that we should only allow immigrants who are high achievers is a logical outcome of the idea that we have obligations to other humans based only on their capacities.

MG and HF: Dependency and interdependency are key concepts in your work. They are also very controversial among disability studies scholars and the disability social movement activists. Based on that controversy, could you tell us a bit more about what you understand as dependency and interdependency?

EK: Well I just had a lovely conversation with a young man with very significant cerebral palsy, whom I met in Korea. He was asking me about the myth of independency that I spoke of, and he asked me to say more about it. After I tried to clarify what I meant, I said, "So, what are you thinking?" And he replied: "I think what you're saying is that you have to have a balance between independency and dependency". And I answered, "Okay, l'll take that." I respond to the point made by a lot of disability scholars that dependency is constructed: "No, the dependency of my daughter is not constructed. She would perish if there was not someone there tending to her needs. And there's nothing constructed about that. But independency is constructed." It's a construct that is an abstraction from all the various dependencies that we decide to make invisible. Like other constructs, it has its use. And certainly, there are many times when we say things like, "don't help me I want to do it myself". Fine. I think of this impulse less in terms of independency, and more as an expression of a desire to be efficacious, to make an imprint on the world. We all want that to some extent or another.

You and I were both at an event about disability, independency and inclusion, which featured a panel with three young people with disabilities, and their parents. I was very interested in what these young people had to say when they were asked what they thought independency was. Only one of them of the three spoke about self-reliance. The other two each talked of "having a sense of yourself; knowing what it is that you want, that you need." If that's what we understand about independency, I accept that as having great value. Coming to know that is not even striving for self-determination, much less self-reliance. (Self-determination and self-reliance are two separable aspects of independency.) It's rather having a sense of who you are - what you care about, or what you need if, as I have come to say, you are to feel right in the world. Such a sense doesn't have to be even a thought that one is able to articulate. You just know: this does not feel good to me; this is not what I want to feel like in this world; or alternatively, this is what I want to feel like in this world. If that's what you call independency, I have no quarrel with independency. But that's not what's understood as independency. Independency is supposed to involve standing on one's own two feet. None of us stand on our own two feet. We are either dependent or we are interdependent. There are times when we might have relative independency. So, if you want to say that the view I endorse is that we need this kind of balance of dependency and independency, I am agreeable to such a formulation.

I had a very moving experience just this past spring in Malta. A wonderful young woman, very self-assured and bright who was a wheelchair user (I don't know what her specific disabilities were) came over to me and said: "you know, I want to thank you for talking about dependency because we get a steady diet of independency, independency, independency. And I tell my boyfriend, I don't want you to help me with this. No. No". And then she said, "That's not really right. It's OK for him to help me." I think that some people with disabilities for whom the mantra has been "independency, independency, independency" may actually appreciate some "balance of independency and dependency."

What I have argued for more recently is what I call managed dependency. The idea here is that you allow yourself to be dependent in certain ways in order for you to have the strength, the time, or the energy to do the things that are most meaningful to you. So, let's say, you need help. You could perhaps struggle to climb (and exhaust yourself) those extra steps, rather than allowing someone to assist you. Similarly, you could spend the time putting on the coat or whatever other 
sort of task you think you are supposed to do "on your own", but then you have less energy and get less time to do the things that are meaningful to you. I think good care can help give us a way to manage dependency - that is, get the help one needs so that one is left with the time, energy, and confidence to do the things that one finds meaningful, or that allows one to be the person one strives to be. The wonderful writer Dave Hingsburger, who works with people with profound intellectual disabilities talks about the stupidity of trying to get people to lace their shoes. Why spend time getting people to lace their shoes when there's Velcro? They can be doing other things with their time - that is managed dependency, and it seems to me the right way to go. We all, even if we aren't disabled, do it in our everyday lives. We take advantage of help and supports in order to do the things that are most important to us, right? So why should we have any different expectations of people with disabilities?

I also think that interdependency is crucial. (I didn't use the term interdependency much in Love's Labor because I think that people very quickly want to go to interdependency and skip dependency completely. I don't think we skip dependency, because there are times when we are simply dependent, not just interdependent.) I now use the term, inextricably interdependent. By this, I mean that, although we may free ourselves of any one relationship in which we are interdependent, we can never free ourselves of all interdependency. For this reason, we are all inextricably interdependent. So rather than focus on independency, we should consider how to manage our dependencies, and we should think about what are the interdependencies that are crucial to who we are.

MG and HF: And how does this conversation relate to the idea of autonomy?

EK: Ok. Everybody wants to know about autonomy. And it's something I always try to avoid. Well, as I said, I do believe that we all have a way in which we want to be in the world. Some things feel right, and some things feel wrong and they vary from individual to individual. And I also believe that we all have agency to some degree, and we want to have some impact on our world, however fleeting. If you want to call those things autonomy, then okay. But this is not "selfgovernance" which is how I think about the philosophical understanding of autonomy. The sort of autonomy I think is most useful to think about is what feminists have called relational autonomy. Relational autonomy is introduced as an alternative to a conception of autonomy that applies to the individual understood as standing on her own, as having some authentic self that is cultivated without the influence of others. Relational autonomy maintains that who we have become as individuals has always been influenced by the relationships we've been in and is always affected by the relationships we currently have. That is, who we are is both a consequence of, and is constituted by, those with whom we have been and are in relationship.

Nonetheless, I avoid talking about autonomy as a goal, or as a supreme good - one that everyone aims for, in large measure because I'm not sure I can speak even of relational autonomy vis-a-vis my daughter. I don't know if people with the kind of very significant disabilities that my daughter has, can have autonomy or be autonomous. But I do think that I have to respect her sense of agency, and I do think I have to respect her sense of what feels right and doesn't feel right. The more stringent autonomy that philosophers often like to talk about, some kind of rational capacity for self-governance in moral matters is, I believe, important and probably ought to be a value we generally embrace - if you have the capacity for this sort of autonomy. But not everyone has those capacities. It's something that contributes to a flourishing life, once again, for those who have the needed capacities for autonomy. But it's not something that is equivalent to a flourishing life. So, it's a good if you have the capacities, but it's not the be all and end all for everybody.

MG and HF: In one of your papers you talk about the importance of not making people more dependent than they need to be. Because people have different capacities and you need to offer support but not more support than people need flourish.

EK: There are all kinds of dependencies that are pernicious. People can be made dependent in very negative ways. Dependency isn't necessarily a good. But it's not necessarily an evil. The point is to allow people to flourish in whatever ways they can flourish. That's always the end. Whether that involves managing certain kinds of dependencies, or whether it involves avoiding certain kinds of (pernicious) dependencies. A person has to come to understand what it is that they need to flourish.

MG and HF: And could you tell us a little more about how a dialogue between independency, dependency, care theories, and disability studies can be made possible.

EK: All social movements strive for freedom, liberation. Sometimes that's called independency. And the disability movement is no different. Certainly, when people are made dependent by built environments that are not suitable to them, when people are made dependent because they're not given the kinds of services or equipment they need, when they are left to sit in their house and be dependent on whomsoever happens to come in to give them an assist, these are 
awful constraints that impede having a flourishing life. The removal of those kinds of constraints are certainly worth fighting for. But the rhetoric of independency is used in such destructive ways by our economic system - impelling people to act in ways that make their lives less good and making them feel lesser because it's an impossible ideal to realize. Therefore, I wish the disability movement wouldn't make independency a centerpiece of the movement. The removal of constraints is certainly a valid way to talk about many of the things that a lot of disabled people struggle against. As is talking about ways that disabled people can be empowered by the appropriate assistance. Of equal importance is recognizing the meaningful connections that are made possible through dependency, and the recognition that dependencies can at times be a good thing, something that can make life rich. Many times, dependency is neither bad nor good - it's just an indifferent fact about our lives that we need to acknowledge to make our lives go well. The rhetoric of independent living, however, has also done a lot of good. But we need to be aware of how strained the notion is in certain situations. Again, to use my daughter as an example. She likes to hold the cup when she's drinking. You can understand why someone would like to be able to do that because when you're drinking you don't want someone pouring something into you, and it is hard to communicate just how much you want and when your helper needs to pull the cup away. Hence the ability to control the cup yourself is really useful. Yet, although she guides the cup, putting it in and taking it out at will, I still need to keep my hand on the cup because she has never been able to learn how to put the cup down. So, shall we say she drinks independently? Well, she's dependent on me in order to be able to drink her cup independently. You see what I mean about the strained way in which we sometimes use the language of independency? What's important to her here is not independency per se, but some measure of control in guiding the cup in and out of her mouth - not for the sake of being in control, but for the sake of drinking well.

MG and HF: On that note, how is it possible to promote strategies to promote the care for people with disabilities based in our inevitable dependency and inextricable interdependency considering how the neo-liberal myth of independency constitutes our way to think about the subject?

EK: Well that's where the use of the concept of independency really does get pernicious. To say everybody has to be out working, for example. Why? And why call some kind of stupid repetitive nothingness of a so-called job "independency" when someone could be sitting painting or listening to music or in the swimming pool, activities which would give the life of the individual much more richness, than the meaningless (and the mostly unproductive - or very minimally productive) "independent job."

MG and HF: And that is the difficulty: dis-mystifying independency as this supreme good and this idea of what being independent is. As if you're only valued if you are...

EK: Productive. But you know the father of capitalism, Adam Smith, extolled the virtue and productivity of the industrial division of labor precisely because he saw that the efficiency of the system meant that enough wealth would be generated so that it would no longer be necessary for everyone to work. He boasted that, at last, children and old people would no longer have to go to work. That's what he saw as the good of capitalism. And here we are in 2019, in the wealthiest country in the history of the world - capitalism par excellence - and state governments in the US are insisting that people too poor and too sick to pay for private health insurance need to fulfill a work requirement in order to receive government sponsored Medicare. It's really scandalous. You know, you do not have to be a Ph.D., and you do not have to be a philosopher, who gets to spend their time thinking about these matters, to say a lot of things I have said. In my new book Learning from My Daughter, one of the chapters is on normalcy and the good life. I talk about the ability to just being able to be. Just being able to appreciate the gifts of being. And I have to say that I was pleased with myself for coming up with this as one component of a good life. Recently I met an advocate for disabled and abused children who works in a hospital. She told me of a woman who would come in frequently because the child she had adopted had very significant disabilities and many serious medical conditions that needed constant monitoring. The mother, she said, was not an educated woman, but she was someone who acted as a foster mother for many and had adopted several of the children who had disabilities. The child in question was the most seriously affected of her children. The adoptive mother took beautiful care of him. In speaking to the advocate, she said: "People always ask me, 'What he do?' Why people always ask me 'What he do?' He be! He be!" She understood what I take to be an extremely profound point about the value of another human being: It's not what he does. He just is. He's just here. And in his case, that is sufficient.

MG and HF: Our last question is on agency and if you would like to comment on that.

EK: Well I think l've already talked about agency. I do think most people want to have some kind of agency in their life and promoting their agency, their ability to do things in the world as 
well as to be, is fine. It's a good thing. My daughter certainly has her agency and definitely has things that she prefers. There are things we ask her to do that she has no interest in doing - and that is equally a part of her agency. We all have some degree of agency. Even if it is just to be. Again, it's having a life that you value, that you have reason to value, and agency is part of that. But a lot of things are part of it - agency is one among a number of possible goods - perhaps a particularly important good. Moreover, it's important to recognize the agency of people who may not manifest agency in ways that are most apparent to us. It is of great urgency that we try not to run roughshod over such agency. It's especially important not to think that because someone has mental disabilities that they have no agency, and so that you can do anything to them that you want. No! And unfortunately, that is what happens because you... because where people don't see any manifest autonomy, they assume a lack of agency and competency, which in turn, gives them license to ignore what that person may want. This is a real problem. In fact, this was something that came up in the Supreme Court hearings of Judge Kavanaugh. While on the bench Kavanaugh had ruled that in the case of a person judged to be incompetent (unable to make important decisions about financial or medical matters) the hospital or guardians could make all their decisions without regard to what the patient seemed to want, prefer or care about. On the basis of Kavanaugh's decision in this case, many in the disability community objected to his appointment to the Supreme Court. They believed, rightly to my mind, that to judge a person incompetent in one (or even several) spheres of activity did not mean that it was right to override any preferences the person might indicate.

MG and HF: And to finish: how old is Sesha right now?

EK: Forty-eight. She's going to be forty-nine in a few weeks. Time flies. She's really matured. And she's very much her own person. She doesn't talk. She can't do anything. But she is so much her own person.

\section{Acknowledgments}

We thank the contributions of Lívia Barbosa Pereira and Cassandra Evans in the elaboration of this interview.

\section{References}

HANIGSBERG, Julia; RUDDICK, Sara. Mother Troubles: Rethinking Contemporary Maternal Dilemmas. Boston: Beacon Press, 1999.

Kittay, Eva Feder. Learning from My Daughter: The Value and Care of Disabled Minds. New York: Oxford UP, 2019.

KITTAY, Eva F. "The Moral Significance of Being Human". Proceedings and Addresses of the American Philosophical Association, 2017.

KITTAY, Eva F; CARLSON, Licia. "Introduction: Rethinking Philosophical Presumptions in Light of Cognitive Disability”. In: KITTAY, Eva F.; CARLSON, Licia (Eds.). Cognitive Disability and Its Challenge to Moral Philosophy. Chischester: Wiley-Blackwell, 2010. p. 1-25.

KITTAY, Eva F. Love's Labor: Essays on Women, Equality and Dependency. New York: Routledge, 1999.

RUDDICK, Sara. Maternal Thinking: Towards a Politics of Peace. Boston: Beacon Press, 1989.

Marivete Gesser (marivete.gesser@ufsc.br) Ph.D. in Psychology (UFSC), Professor in the Graduate Program at the Federal University of Santa Catarina (UFSC) and Coordinator of the Center for Disability Studies (NED). She studies the intersections of gender, sexuality, race, poverty, and disability in Brazil; public policy and human rights; disability justice and inclusive education.

Helena Fietz (helenafietz@gmail.com) is a sociocultural anthropologist whose research focuses on care practices and disability in Brazil. In dialogue with sociocultural and medical anthropology, feminist science and technology studies (STS) and disability studies, her work examines how infrastructures of care, family expectations, public representations of disability, and public policies intersect in the lives of people with intellectual disabilities and their families in Brazil. 
HOW TO CITE THIS ARTICLE ACCORDING TO THE JOURNAL'S NORMS

GESSER, Marivete; FIETZ, Helena. "Ethics of Care and the Experience of Disability: an Interview with Eva Feder Kittay". Revista Estudos Feministas, Florianópolis, v. 29, n. 2, e64987, 2021.

\section{AUTORSHIP CONTRIBUITION}

Marivete Gesser contacted the interviewee, and in collaboration with the second author, prepared the questions and conducted and transcribed the interview.

Helena Fietz collaborated in the development of the questions and on conducting and transcribing the interview.

\section{FINANCIAL SUPPORT}

The present interview counted with the support of the Coordenação de Aperfeiçoamento de Pessoal de Nível Superior - Brasil (CAPES) through projects numbers 88881.169887/2018-01 and 88881.190257/2018-01.

\section{CONSENT TO USE IMAGE}

Not applicable.

\section{APPROVAL BY RESEARCH ETHICS COMMITTEE}

Not applicable.

\section{CONFLICT OF INTERESTS}

Not applicable.

\section{USE LICENSE}

This article is licensed under the Creative Commons License CC-BY 4.0 International. With this license you can share, adapt, create for any purpose, as long as you assign the authorship of the work.

\section{BACKGROUND}

Received 03/05/2019

Approved 28/02/2020

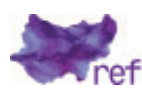

